Check for updates

Berkshire

Cite this as: BMJ 2021;372:n442 http://dx.doi.org/10.1136/bmj.n442 Published: 17 February 2021

\title{
EXCLUSIVE
}

\section{Covid-19: NHS trusts deny restricting PPE during pandemic}

\section{David Oliver}

NHS trusts have denied issuing instructions to staff to restrict their use of personal protective equipment (PPE) during the pandemic, despite hundreds of reports from doctors that trusts did so last year.

Trusts also denied that they had issued warnings to staff who had raised concerns about PPE supplies being inadequate, despite reports from doctors that this had happened, an investigation by The BMJ has found.

Many trusts said that they had reminded staff periodically of the need to adhere to locally adopted national guidelines from national organisations such as Public Health England over PPE specification and to use PPE wisely or appropriately. The UK parliamentary public spending watchdog reported this week that the government had wasted hundreds of millions of pounds on poor quality and unusable PPE that left frontline workers insufficiently protected from covid-19. ${ }^{1}$

Only one trust admitted that deaths from covid-19 among its staff were being investigated by the Health and Safety Executive (HSE). Yet over 6oo NHS staff have died from covid-19, and the HSE has said that it holds data on closed or open investigations at an undisclosed number of trusts.

\section{Freedom of information requests}

The BMJ sent freedom of information requests to 130 NHS trusts in England asking about their policies on covid-19 PPE in 2020 (see box). Of the 66 trusts that replied (50\%), 6o denied issuing instructions to restrict PPE use, five refused to respond to the freedom of information request, and one said that it did not hold the information requested.

Of the trusts that responded, one-Guy's and St Thomas' NHS Foundation Trust-confirmed that it had issued an informal warning to one staff member over PPE use, and one-Chelsea and Westminster Hospital NHS Foundation Trust-said that it had warned a staff member over PPE related comments made on social media.

Last year, however, the Doctors' Association UK, a not for profit medical membership organisation (working in partnership with Messly, a doctors' careers and recruitment platform) logged over 1500 reports nationally highlighting inadequate access to PPE, plus an additional 220 reports about frontline doctors being warned, threatened, disciplined, or made to feel bullied or unsupported for raising issues about PPE

The BMJ sent a separate freedom of information request to NHS England asking whether it had issued any communication to trusts from 1 March to 30
September 2020 about whether or how to discuss PPE specification, qualities, supplies, or availability in mainstream or social media and whether it had vetted, vetoed, or approved any communications from NHS trusts on these issues. "NHS England did not issue any communications to trusts regarding their own communication on personal protective equipment (PPE)," it responded.

But senior NHS sources, who did not wish to be named, questioned this, telling The BMJ that NHS England had vetted and vetoed covid related communications from trusts during the pandemic.

\section{Investigating staff deaths}

In response to The BMJ's inquiry only one trust, Pennine Acute Hospitals NHS Trust, admitted being under investigation by the HSE for covid-19 deaths among staff. The trust said that it reported fewer than 10 staff deaths to the HSE from 1 May to 30 November 2020. "The HSE received the trust's investigation report and to date have taken no further action," the trust said.

The HSE admitted in response to a separate freedom of information request from The BMJ that it held information relating to investigations at an undisclosed number of trusts over staff covid deaths and sickness. But it would not disclose the total number of trusts investigated, would not say whether those investigations were closed or open under the freedom of information cost exemption, and was not prepared to name the trusts involved.

Katie Sanderson, spokesperson for the Doctors' Association UK, said that the process of investigating staff deaths had lacked consistency. "We know that the appalling death toll of 882 frontline health and social care workers will continue to rise if no action is taken," she said. "The investigation of these deaths has been piecemeal and inconsistent.

"We owe it to those who have lost their lives to learn from the circumstances surrounding their deaths, and we should be aiming for a situation where no healthcare workers contract covid-19 at work."

\section{Adhering to guidelines}

Chris Hopson, chief executive of NHS Providers, which represents NHS trusts, said that trusts were led on PPE use by experts at Public Health England.

He said, "We know that the national guidance is based on careful, and full, expert consideration of all the most up to date scientific evidence and is reviewed in light of any changing circumstances.

“Trust leaders are deeply aware of staff concerns around PPE and will always do everything they can 
to listen carefully to, and meet, those concerns, including reassigning staff [who are] at high risk or uncomfortable with national guidance wherever they can.”

But, in response to The BMJ's findings, Jenny Vaughan, Doctors' Association vice chair and NHS consultant, said, "We do not feel that the PPE currently mandated by Public Health England offers healthcare workers an acceptable level of protection, and we are calling for the guidance to be urgently revised to ensure that all staff exposed to covid-19 have access to high level respiratory protection.

"There is also a clear lottery among hospital trusts: some are defying Public Health England rules to give their staff the protection they deserve due to concerns about hospital spread of the virus.”

A Department of Health and Social Care spokesperson said, "As the NAO [National Audit Office] recognised, during the pandemic all of the NHS providers audited were always able to get what they needed in time."

\section{What the BMJ asked trusts \\ Freedom of information requests were sent to 130 acute, community, integrated, and ambulance trusts. \\ Each trust was asked whether, from 1 March to 30 September 2020, it had issued communications to staff suggesting that their use of PPE was excessive (in terms of volume of specification), whether it had warned or disciplined staff (formally or informally) over PPE use, and whether it had warned or disciplined staff for speaking out over PPE shortages in social or news media. \\ Trusts were also asked whether they had been subjected to any investigation from the Health and Safety Executive from 1 May to 30 November 2020 over staff deaths from covid-19, PPE use, or hospital acquired covid-19 infections among staff.}

\section{Addendum: On 17 February 2021 we amended this story to add that the Doctors' Association} UK's data were gathered in cooperation with Messly.

1 Dyer C. Covid-19: Government wasted millions on poor quality PPE, spending watchdog finds. BMJ 2021;372:n399. doi: 10.1136/bmj.n399 pmid: 33568391

This article is made freely available for use in accordance with BMJ's website terms and conditions for the duration of the covid-19 pandemic or until otherwise determined by BMJ. You may use, download and print the article for any lawful, non-commercial purpose (including text and data mining) provided that all copyright notices and trade marks are retained. 